W.-K. AN, M.-Y. HAN, C.-A. WANG, S.-M. YU, Y. ZHANG, S. BAI, W. WANG* (LANZHOU UNIVERSITY AND COLLABORATIVE INNOVATION CENTER OF CHEMICAL SCIENCE AND ENGINEERING, TIANJIN, P. R. OF CHINA)

Insights into the Asymmetric Heterogeneous Catalysis in Porous Organic Polymers: Constructing a TADDOLEmbedded Chiral Catalyst for Studying the Structure-Activity Relationship

Chem. Eur. J. 2014, 20, 11019-11028.

\title{
An Organo Porous Polymer Catalyst for Asymmetric Alkylation with $\mathrm{Et}_{2} \mathrm{Zn}$
}

\section{Category}

Polymer-Supported Synthesis

\section{Key words}

porous organic polymers

aldehydes

heterogeneous catalysis

\section{SYNFACThin}

Preparation of the TADDOL-CPP catalyst:<smiles>CC[C@H]1OC(C)(C)OC1OC</smiles><smiles>[Mg]C#Cc1ccc(Br)cc1</smiles>

1. $\mathrm{Mg}, \mathrm{I}_{2}, \mathrm{THF}, 80^{\circ} \mathrm{C}, 7 \mathrm{~h}$<smiles>Brc1ccc(C(c2ccc(Br)cc2)(c2ccc(Br)cc2)c2ccc(Br)c(Br)c2)cc1</smiles>

$\left[\mathrm{Pd}\left(\mathrm{PPh}_{3}\right)_{2} \mathrm{Cl}_{2}\right], \mathrm{Cul}, \mathrm{Ph}_{3} \mathrm{P}, \mathrm{DMF}, \mathrm{Et}_{3} \mathrm{~N}$ under $\mathrm{Ar}, 80^{\circ} \mathrm{C}, 72 \mathrm{~h}$

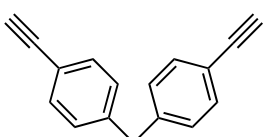

Significance: A chiral $\alpha, \alpha, \alpha^{\prime}, \alpha^{\prime}$-tetraaryl-1,3-dioxolane-4,5-dimethanol-based chiral porous polymer (TADDOL-CPP) was prepared and applied to the asymmetric alkylation of aromatic aldehydes with $\mathrm{Et}_{2} \mathrm{Zn}$ in the presence of $\left[\mathrm{Ti}(\mathrm{O} i-\mathrm{Pr})_{4}\right]$ to give the corresponding products $\mathbf{1 a - i}$ in up to $96 \%$ yield with up to $94 \%$ ee.
Comment: The TADDOL-CPP as well as the TADDOL-CPP/Ti catalysts were characterized by ${ }^{13} \mathrm{C}$ CP/MAS NMR spectroscopy, TGA, BET, XRD, TEM and ICP analyses. TADDOL-CPP was recovered by centrifugation and reused ten times to give 1a with slight loss of the catalytic activity (91\% ee to $75 \%$ ee). 